\title{
HYDROGEOCHEMICAL EVOLUTION OF MESOZOIC AQUIFERS IN THE SOUTHERN PARANÁ BASIN IN WESTERN RIO GRANDE DO SUL STATE, BRAZIL
}

\author{
EVOLUÇÃO HIDROGEOQUÍMICA DOS AQUÍFEROS \\ MESOZOICOS DA PORÇÃO SUL DA BACIA DO PARANÁ NO OESTE \\ DO ESTADO DO RIO GRANDE DO SUL, BRASIL
}

ABAS

ASSOCIAÇĀO BRASILEIRA DE
AGUAS SUBTERRANEAS

www.abas.org

Guilherme Vargas Teixeira ${ }^{1}$; Antonio Pedro Viero ${ }^{2}$

Artigo recebido em: 27/01/2016 e aceito para publicação em: 05/11/2016.

DOI: http://dx.doi.org/10.14295/ras.v31i1.28577

\begin{abstract}
The western region of Rio Grande do Sul is marked by successive water supply crisis during the dry season. Hydrogeological, hydrogeochemical and structural studies were done to understand the dynamics of groundwater flow in the aquifers of the region. The aquifers are the Guarani Aquifer System (SAG) and Serra Geral Aquifer System (SASG). Approximately $90 \%$ of the wells capture groundwater exclusively from the SASG, while 10\% capture from SAG. The SAG consists of four sedimentary hydrostratigraphic units: Botucatu, Guará and Pirambóia Formations and Rosário do Sul Group, while the SGAS consists of one hydrostratigraphic unit, the Serra Geral Formation. The main objective of this study is the hydrogeochemical characterization of JuroCretaceous aquifers from the region. The hydrochemical data are from the SIAGAS database, belonging to Brazilian Geological Survey (CPRM). Statistical analysis by principal components and clustering identified three groundwater groups, confirmed by dispersion diagrams. Group 1 groundwater percolates only the SGAS while Groups 2 and 3 show sodium enrichment indicating mixture with groundwater from deeper, confined sedimentary aquifers of the Paraná Basin. The enrichment in sodium results from cation exchange of calcium from clay minerals. In addition to sodium, ions like fluoride, sulfate and chloride appear with significant concentrations in many wells. They could be originated in the Irati Formation, which is stratigraphically below the SASG and SAG.
\end{abstract}

Keywords: Hydrogeology. Hydrochemistry. Guarani Aquifer System. Serra Geral Aquifer System.

Resumo: A região oeste do Rio Grande do Sul é marcada por sucessivas crises no abastecimento durante a estação seca. Estudos hidrogeológicos, hidroquímicos e estruturais foram feitos para entender a dinâmica do fluxo subterrâneo dos aquíferos da região. Os aqüíferos do estudo são o Sistema Aquífero Guarani (SAG) e o Sistema Aquífero Serra Geral (SASG). Aproximadamente 90\% dos poços capturam água exclusivamente no SASG, enquanto $10 \%$ captam água no SAG. O SAG consiste de quatro unidades sedimentares hidroestratigráficas: Botucatu, as Formações Guará e Pirambóia e o Grupo Rosário do Sul, enquanto o SASG consiste de uma unidade hidroestratigráfica, a Formação Serra Geral. O principal objetivo deste estudo é a caracterização hidrogeoquímica dos aquíferos juro-cretáceos da região. Os dados hidroquímicos são do banco de dados do SIAGAS, pertencente ao Serviço Geológico do Brasil (CPRM). Análises estatísticas por componentes principais e método de agrupamento por distância identificaram três grupos, confirmados pelos diagramas de dispersão. O grupo 1 percola apenas no SASG, enquanto os grupos 2 e 3 mostram enriquecimento em sódio indicando mistura com águas profundas provenientes de aqüíferos confinados sedimentares da bacia do Paraná. O enriquecimento de sódio resulta da troca de cátions em argilas. Além do sódio, íons como sulfato, cloreto e fluoreto aparecem com concentrações significativas em muitos poços. Eles podem ter sido originados da Formação Irati, que está estratigraficamente abaixo do SAG e do SASG.

Palavras-chave: Hidrogeologia. Hidroquímica. Aquífero Guarani. Aquífero Serra Geral.

1-2 Universidade Federal do Rio Grande do Sul (UFRGS), Porto Alegre, RS - E-mails: (teixeira_guilherme@yahoo.com.br; antonio.pedro@ufrgs.br) 


\section{INTRODUCTION}

The growing demand of groundwater for human supply in Rio Grande do Sul state, southern Brazil, requires detailed hydrogeological studies to ensure quality and potability of this resource used by public and private suppliers.

Over the past few decades, thousands of wells were installed in the southern Paraná Basin, Rio Grande do Sul state, without geological and hydrogeological criteria necessary for the correct use of aquifers. Technical knowledge remained deficient for decades in the state as a result of the lack of hydrogeologic surveys that would aim at the appropriate qualitative and quantitative characterization and understanding of the geochemical processes in the aquifers. Very little is known scientifically about the structural geology and potential of the aquifers of the region. This constitutes a barrier to the establishment of criteria and appropriate policies for the management of the aquifers.

The use of groundwater is intense in the study area, according to the number of registered wells in the Groundwater Information System of the Brazilian Geological Survey (Serviço Geológico do Brazil-CPRM). The study area has its economy based on agriculture and livestock, including soybean, maize and rice, according to the census of the Brazilian Institute of Geography and Statistics (IBGE, 2006). The potential contamination of groundwater is caused by technical agriculture with intensive use of fertilizers and pesticides and poor sanitation structure, partial collection and treatment of urban sewage. Despite these sources of contamination, the risk is minimized by thick soil (STRECK et al., 2008), which lowers vulnerability to contamination.

According to Madramootoo (2012), the rapid expansion of irrigation, with few regulatory measures and control mechanisms, leads to loss of water quality and depletion cones. Furthermore, contamination of aquifers by percolation and accumulation of agroche- micals may become irreversible.

Research on the use of groundwater in agriculture is concentrated in the last three decades. Saudi Arabia basically relies on the use of groundwater. Other regions also use intensely groundwater, such as large parts of Australia, Tunisia and Jordan. India and China are the major groundwater consumers in agriculture. In China, all forms of production are based on groundwater, except rice.

In the United States, the sandy soils are quite permeable and highly vulnerable to contamination (MAYZELLE ET AL, 2015). Major $\mathrm{NO}_{3}{ }^{-}$sources of groundwater contamination are manure (6\%), fruit areas and pigs rearing (33\%). Part of the solution may be the replacement by cultures based on alfalfa and wineries. Further improvement may be caused by recharge of clean water into the wells to reduce the amount of nitrate.

Drilling of wells is still uncontrolled in the studied region and most wells have neither register of lithological, construction and hydrochemical data nor pump tests. The public database (CPRM, 2005) presents a large number of wells with location, total discharge, lithological description, constructive profile and chemical analysis, although some wells do not have complete chemical analysis. This is a great advance in the current situation of drilling wells and an important source of information for the management of groundwater.

Quantitative and qualitative models of hydrogeochemical processes that define the chemical composition of groundwater are proposed in this study. These models are based on groundwater chemical data and geological characteristics of aquifers. In addition, they may be helpful in the management and adequate use of groundwater in the study area. The overall objective of this study is the hydrogeological and hydrochemical characterization of the Serra Geral (SGAS) and Guarani Aquifer Systems (SAG) in the western region of Rio Grande do Sul State, southern Paraná Basin. The specific objectives are the determination of the geochemical characteristics of groundwater of SGAS and SAG in the region, correlate the 
chemical composition of groundwater and tectonic lineaments affecting the aquifers, evaluate the occurrence of mixture of groundwater from different aquifers and generate data to be used as parameters for the correct management of groundwater in the region.

\section{STUDY AREA}

The study area covers 56 municipalities Fig. 1) and comprises part of the West, Central and North Tectonic Compartments of the SAG and SGAS (MACHADO, 2005). The SAG (Figure 2) is confined by the SGAS and consists mainly of eolic arenites composed of quartz and subordinate K-fedspar. The groundwater composition is predominantly calcium and sodium bicarbonated and concentration of total dissolved solids is lower than $150 \mathrm{mg} / \mathrm{L}$ in most wells (CPRM, 2005).

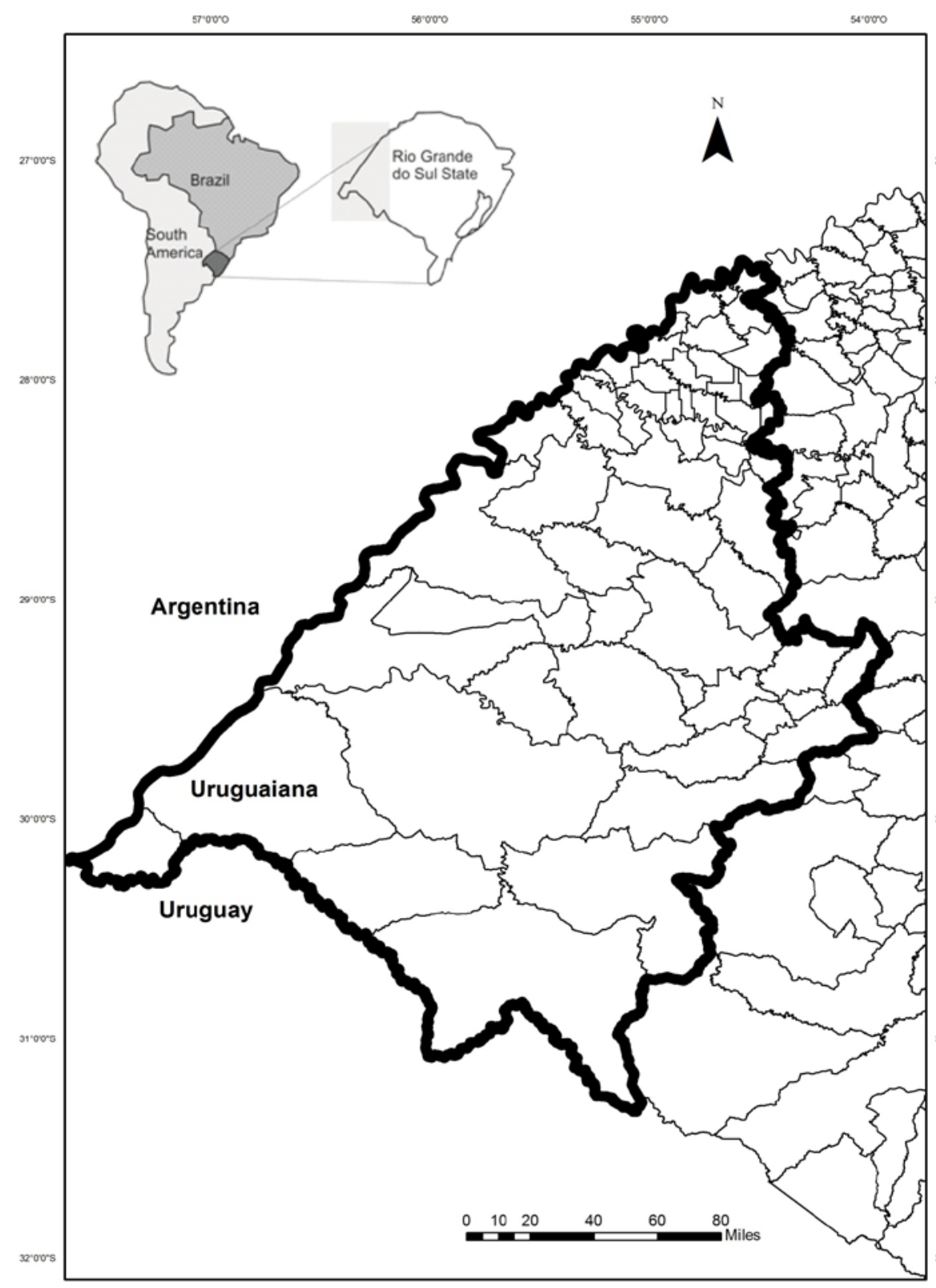

Figure 1 - Localization of Study Area delimited by black line

Figura 1 - Localização da área de estudos delimitada pela linha preta 


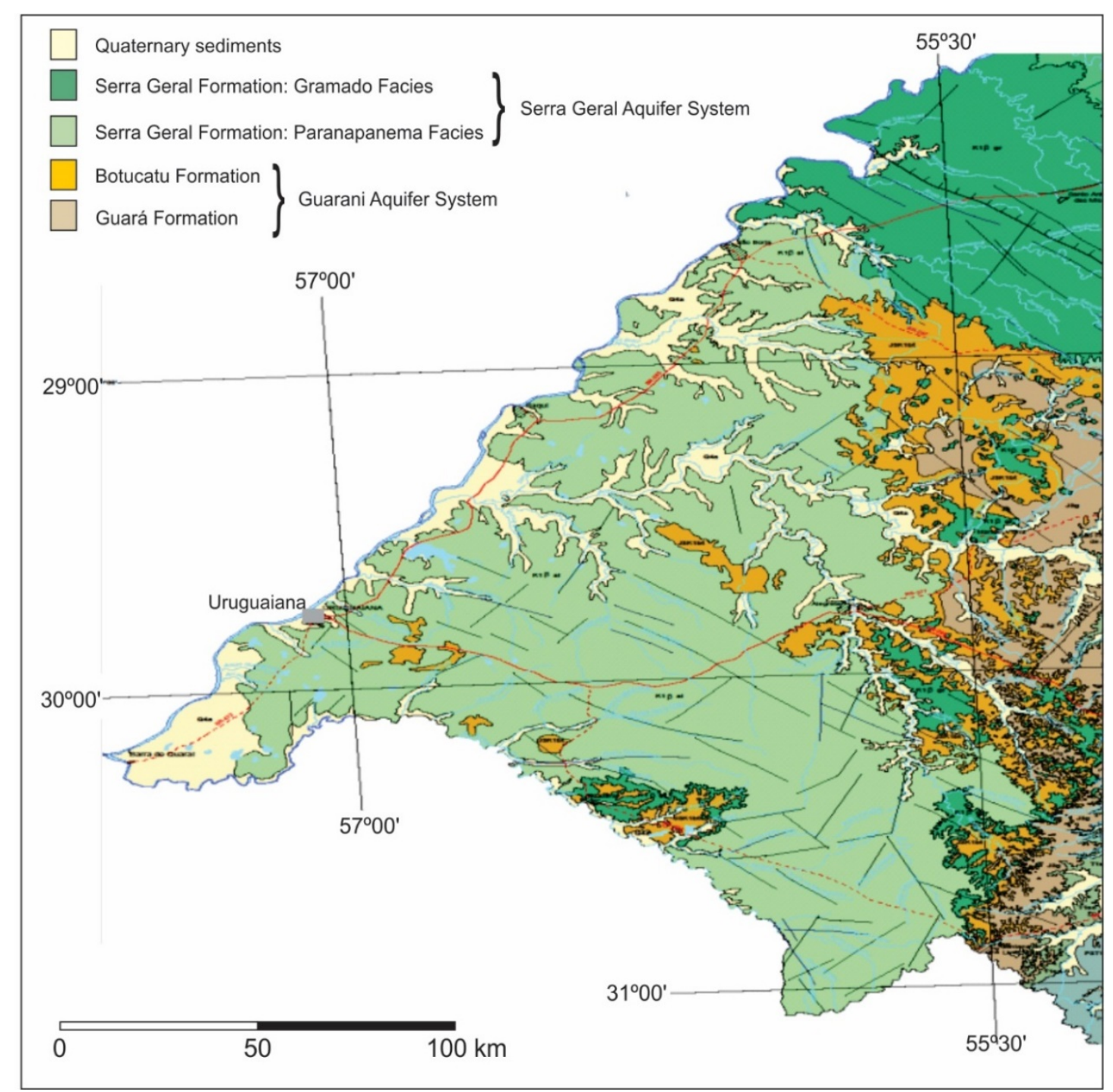

Figure 2 - Hidrogeology units of Study Area. Serra Geral Aquifer System predominates in the area. The Guarani Aquifer System has few outcrops in the area and is stratigraphically below the Serra Geral Aquifer System (Modified from Machado and Freitas, 2005). BR-290: Federal Highway

Figura 2 - Unidades hidrogeológicas da área estudada. O Aquífero Serra Geral predomina na área. O Sistema Aquífero Guarani tem poucos afloramentos na área e está estratigraficamente abaixo do Sistema Aquífero Serra Geral (modificado de Machado e Freitas, 2005). BR-290: Rodovia Federal

SASG is stratigraphically above the SAG (Fig. 2), and is composed of volcanic rocks and represents one of the main manifestation of intraplate vulcanism on Earth history. In the studied area, the SGAS presents basically calcic bicarbonated and magnesian groundwater (CPRM, 2005). Some wells register sodium bicarbonated groundwater indicating mixtures with groundwater from SAG that ascended through fractures. The salinity is very low due to weak rock-water interaction, except in some places where either the basalts have amygdales filled with calcite or there is mixture with groundwater from deeper aquifers. The dissolution of calcite from amygdales increases the calcium and bicarbonate concentrations while the mixture with aquifers results in the increase of sodium and other ions.

High salinity is recorded in some places of the SASG and SAG, caused by mixing with groundwater from lower strata in the stratigraphic sequence that ascended through faults and fractures. The mineralogical composition of the rocks of the SASG and SAG is not compatible with the content and composition of total dissolved solids in many wells of these hydrostratigraphic units. The 
rise of ancient and deep groundwater is the most probable cause of salinization in such aquifers (BITTENCOURT ET AL., 2003).

The deep groundwater concerned is mainly from the Irati hydrostratigraphic unit. The Irati is a succession of (a) Dark grey siltyclayey shales, not bituminous, with thin conglomeratic sandstone and mudstone layers (Taquaral Formation), (b) black clay shales, bituminous, in a few cases intercalated with beds of carbonate rocks (dolomite marl) and thin centimetric lenses of nodular flint and few evaporates (Gypsite and anhydrite), covered by clayey-siltic shale and mudstones (Membro Morro do Alto), and (c) carbonates (dolomites intercalated with sandstones at the base) and bituminous shale and clay, with or without interleaved carbonates (HACHIRO, 1997). According to CPRM (1986), there is a layer of gypsum and halite in th sequence. Gypsum is the likely source of sulfate, while halite is the source of sodium.

\section{METHODS}

This study was carried out based mainly on hydrogeological and hydrochemical data published in the SIAGAS database of the Brazilian Geological Survey (CPRM, 2016) and comprises several activities. A data file was organized containing 2,760 wells of which 220 have hydrochemical data so they were in this study. Overall, 1,000 wells present hydrogeological data such as depth, geological profile and pumping rate. The hydrochemical parameters used in this study are electrical conductivity (EC), $\mathrm{Ca}^{2+}, \mathrm{Na}^{+}, \mathrm{Cl}^{-}$ , hardness and total alkalinity. Magnesium, fluoride and sulfate were analyzed based on their original parameters and were not included in the cluster analysis. Potassium was not considered because of the small number of data available in the database. Magnesium and sulphate were analysed. The data were evaluated statistically and wells with spurious values were eliminated from the analysis. About $90 \%$ of the wells capture groundwater only in the Serra Geral Aquifer System while the remaining $10 \%$ (near to 260 wells), capture groundwater from SAG and
SASG.

Multivariate statistical analysis of hydrochemical data using SPSS software (version 18) were carried out to verify the existence of different chemical types of groundwater in the studied aquifers. Factor analysis was initially carried out for the main components, and from these results we proceeded to cluster analysis. The cluster analysis separates samples into hydrochemically similar populations individualizing different groups of groundwater. The parameters used in the statistical analysis were electric conductivity, total hardness, total alkalinity, chlorine, sodium, and calcium, as they are analized in a large number of wells.

According to Viccini (2005), the PCA has the main objective to reduce the number of variables present in the database through the synthesis of new variables. This reduction is made transforming the original variables into new ones, maintaining most of the initial variability of the set. In practice, the algorithm is based on the variance-covariance matrix or correlation matrix, from which the eigenvectors and eigenvalues are extracted.

The principal components analyses replace a set of correlated variables from the original database to a set of new, uncorrelated variables and place them in descending order by their variances. The new variables are called CP and have statistical independence and are not correlated. This means that the ACP do not offer any advantage if the original variables are not correlated.

The clustering method comprises a variety of algorithms and techniques with the purpose to separate objects in similar groups. In this method, unlike the principal component method, the grouping is not done by means of variance-covariance matrices. It is done through the calculation of distance and the Euclidean distance is the most used. This method uses a graphical tool of great practicality denominated dendrogram.

The basic process of all agglomerative methods is similar. It starts with the calculation of distance between the variables and ends with the dendrogram, where the 
successive mergers of the groups to form a single larger group can be checked. A dendrogram can be represented in both vertical and horizontal form. A dendrogram provides a visual summary of the clustering processes, presenting a picture of the groups and their proximity with a drastic reduction in dimensionality of the original date (KAZI ET AL., 2009).

\section{RESULTS AND DISCUSSION}

The hydrogeological and hydrochemical data were processed and interpreted by binary chemical correlation diagrams and the correlation with tectonic lineaments. The relationships of hydrochemical character with tectonic lineaments were evaluated by overlay concentration distribution maps with tectonic lineament and density lineament maps. High density lineament zones indicate potential connections between aquifers from different depths, enhancing the occurrence of mixing groundwater processes. According to Teixeira and Viero (2015), large tectonic lineaments generally coincide with the highest pumping rates of wells from the SASG.

The hydrogeological parameters of the SASG and SAG identified in wells from the region are presented and discussed in this section. The hydrogeological parameters relate to the behaviour of the aquifer as intrinsic characteristics.

\subsection{Hydrogeochemistry}

Statistical analysis identified three chemical groups of groundwater in the study area (Table 2). The discrimination of these groups supports the identification of the source of the ions dissolved in groundwater and also indicates the aquifer characteristics where groundwater circulated. It is common that groundwater of SASG suffered mixture with deeper hydrostratigraphic units connected through regional fractures and faults (KERN ET AL., 2008., NANNI ET AL., 2013).

The correlation coefficients between the chemical and physico-chemical parameters used in the statistical analysis are observed in Table 1. Correlation coefficients greater than 0.5 for EC and total alkalinity, EC and chlorine, EC and sodium, total alkalinity and calcium and total alkalinity and sodium. Total alkalinity has a better correlation with sodium than calcium, which indicates cation exchange processes in the aquifer. In aquifers contamined with seawater, the correlation between chlorine and the electric conductivity is near 0.9, as shown by Palacio et al., (2011) in coastal aquifer study.

Table 1 - Coefficient of correlation between the parameters used in statistical analysis with SPSS software

Tabela 1 - Coeficiente de correlação entre os parâmetros usados na análise estatística com o software SPSS

\begin{tabular}{cccccccc}
\hline & & EC & Total & Ca & Cl & Total & Na \\
& & & Alkalinity & & & Hardness & \\
\hline EC & Pearson Correlation & 1.0 & 0.8 & 0.50 & 0.60 & 0.53 & 0.65 \\
& $\mathrm{~N}$ & 355.0 & 355.0 & 354.00 & 334.00 & 354.00 & 351.00 \\
Total & Pearson Correlation & 0.8 & 1.0 & 0.54 & 0.31 & 0.56 & 0.61 \\
Alkalinity & $\mathrm{N}$ & 355.0 & 355.0 & 354.00 & 334.00 & 354.00 & 351.00 \\
Calcium & Pearson Correlation & 0.5 & 0.5 & 1.00 & 0.41 & 0.93 & -0.01 \\
(Ca) & $\mathrm{N}$ & 354.0 & 354.0 & 354.00 & 333.00 & 353.00 & 350.00 \\
Chloride(Cl) & Pearson Correlation & 0.6 & 0.3 & 0.41 & 1.00 & 0.46 & 0.39 \\
& $\mathrm{~N}$ & 334.0 & 334.0 & 333.00 & 334.00 & 333.00 & 331.00 \\
Total & Pearson Correlation & 0.5 & 0.6 & 0.93 & 0.46 & 1.00 & 0.00 \\
Hardness & $\mathrm{N}$ & 354.0 & 354.0 & 353.00 & 333.00 & 354.00 & 350.00 \\
Sodium (Na) & Pearson Correlation & 0.6 & 0.6 & -0.01 & 0.39 & 0.00 & 1.00 \\
& $\mathrm{~N}$ & 351.0 & 351.0 & 350.00 & 331.00 & 350.00 & 351.00 \\
\hline
\end{tabular}


Table 2 - Two principal components generated from original data using SPSS software

Tabela 2 - Dois componentes principais gerados a partir de dados originais usando o software SPSS

\begin{tabular}{lcc}
\hline Parameter & \multicolumn{2}{c}{ Components } \\
\hline Sodium & 1 & 2 \\
Cond. Eletric & 0.939 & -211 \\
Total & 0.831 & 0.409 \\
Alkalinity & 0.744 & 0.430 \\
Cloret & 0.558 & 0.409 \\
Hardness & 0.178 & 0.961 \\
Calcium & 0.144 & 0.958 \\
\hline
\end{tabular}

The values of the principal components 1 and 2 for the analysed parameters are shown in Table 2. Component 1 shows values greater than 0.68 for electric condutivity, total alkalinity and sodium. Chloride, despite having value below 0.68 , correlates better with component 1 than 2. Component 2, on the other hand, has significant values only for calcium and hardness.

According to Koretsky (2000), many surface hydroxyl groups have amphoteric characteristics (i.e. they may protonate or deprotonate) as shown by the following reaction:

$\mathrm{SOH}^{-}+\mathrm{H}^{+} \leftrightarrow \mathrm{SOH}_{2}{ }^{+}$ou $\mathrm{SOH} \leftrightarrow \mathrm{SO}^{-}+\mathrm{H}^{+}$ where $\mathrm{SOH}^{-}$is the hydroxyl of surface crystalline structure. These reactions depend on the $\mathrm{pH}$ of the solution. The adsorption of metals on the mineral surface must occur through exchange of a proton, while ligands will be adsorbed through the $\mathrm{OH}^{-}$substitution. The adsorbed metal will add another ligand, and this in turn will add another one in a string mode. After the adsorption, the exchange of $\mathrm{Na}^{+}$for $\mathrm{Ca}^{2+}$ occurs (WHITE, 2013). The $\mathrm{pH}$ at which positively and negatively charged sites balance in a given mineral to give a neutral surface is known as the $\mathrm{pH}$ of the point of zero charge (pHZPC).

Calcium and sodium are important componentes of groundwater salinity. In groundwater, sodium is more soluble than calcium, which tends to precipitate as calcite when its concentration is relatively high. Sodium, in the other hand, doesn't precipitate but can be adsorbed by oxides, clays and organic compounds. Dissolved calcium in groundwater tends to replace by cation exchange the sodium adsorbed in minerals.

According to Meng et al.,(2001), the origin of sodium in SAG is probably from two different sources, either as a product of feldspar dissolution or the result of saline intrusion. However, we must mention that the feldspar is rare and there is no correlation between sodium and chloride in the SAG. Ment et al.,(2001) say that high $\mathrm{HCO}_{3}{ }^{-}$ concentration indicates that calcite dissolution is dominant in the area and $\mathrm{Ca}^{++}$concentration is directly related to this dissolution.

The $\mathrm{Na}^{+}$concentration tends to increase in deeper portions of the SAG. The chemical composition of the groundwater ranges from calcium bicarbonate near the recharge zone to sodium bicarbonate in confined portions (GASTMANS ET AL, 2010). Petalas et al. (2009) observed that calcite dissolution is favored by exchange of sodium by calcium. The dissolution of gypsum is very common in the Paraná Basin, and enhances the additional exchange of $\mathrm{Ca}^{2+}$ by $\mathrm{Na}^{+}$in the aquifer (APPELO AND POSTMA, 2005). Clark and Fritz (1997) mention that high $\mathrm{Na}^{+}$ concentrations in groundwater are associated with the decrease of $\mathrm{Ca}^{2+}$ and $\mathrm{Mg}^{2+}$ in response to ion exchange, mainly by clay minerals.

The distribution of chemical groups is shown in Figure 3. Group 1 and Group 3 occur in the entire studied area, while Group 2 is registered mainly in the southwest and west portions. Group 1 has very low concentrations of sodium, much lower than the other groups. In this group, calcium and bicarbonate are the main dissolved ions characterizing the groundwater as bicarbonate calcic. Groups 2 
and 3, in addition to calcium, also have higher sodium and sulphate, with the largest concentrations of sodium in Group 3 (Table
3). Group 3 also has the highest concentrations of fluoride with values up to $2.2 \mathrm{mg} / \mathrm{L}$.

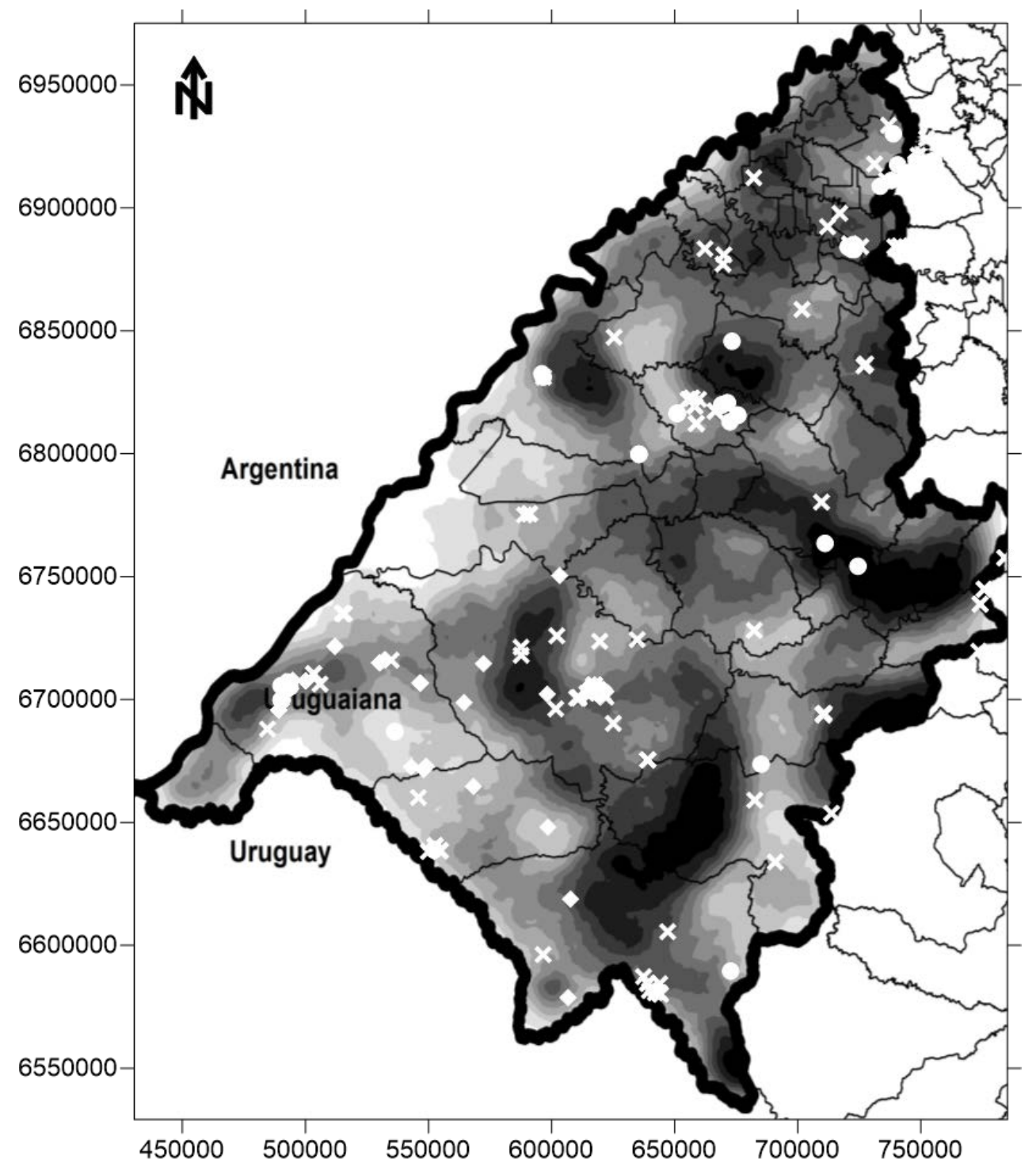

Figure 3 - Distribution map of groundwater groups. White cross: Group 1; white lozenge: Group 2; white circle: Group 3

Figura 3 - Mapa de distribuição dos grupos de água subterrânea. Cruz branca: Grupo 1; lozango branco: Grupo 2; círculo branco: Grupo 3 
Table 3 - Statistical summary of hydrochemical data of groundwater from study area

Tabela 3 - Sumário estatístico de dados hidroquímicos dos aquíferos da área de estudo

\begin{tabular}{|c|c|c|c|c|c|c|c|c|c|c|}
\hline & & EC & $\begin{array}{c}\text { Total } \\
\text { Alkalinity }\end{array}$ & Hardness & $\mathrm{Ca}^{2+}$ & $\mathrm{Na}^{+}$ & $\mathrm{Cl}^{-}$ & $\mathrm{SO}_{4}^{-}$ & $\mathrm{F}^{-}$ & $\mathrm{Mg}^{2+}$ \\
\hline & & $\mu \mathrm{S} / \mathrm{cm}$ & \multicolumn{2}{|c|}{$\mathrm{mg} / \mathrm{L}-\mathrm{CaCO}_{3}$} & \multicolumn{6}{|c|}{$\mathrm{mg} / \mathrm{L}$} \\
\hline \multirow{5}{*}{$\begin{array}{c}\text { All } \\
\text { Samples }\end{array}$} & Average & 324.0 & 139.1 & 105.1 & 23.7 & 35.0 & 15.5 & 14.3 & 0.4 & 10.1 \\
\hline & $\mathrm{SD}$ & 218.0 & 87.0 & 107.0 & 22.9 & 39.0 & 22.7 & 27.1 & 0.36 & 13.6 \\
\hline & Minimum & 16.0 & 1.0 & nd & nd & nd & nd & nd & nd & nd \\
\hline & Maximum & 1420.0 & 402.3 & 743.0 & 170.7 & 188.0 & 134.1 & 250.0 & 2.2 & 90.4 \\
\hline & $\mathrm{N}$ & 203.0 & 177.0 & 178.0 & 175.0 & 180.0 & 179.0 & 157.0 & 140 & 160 \\
\hline \multirow{5}{*}{ Group 1} & Average & 194.6 & 88.3 & 78.4 & 19.6 & 10.5 & 6.9 & 6.2 & 0.26 & 6.9 \\
\hline & $\mathrm{SD}$ & 104.9 & 58.5 & 50.5 & 13.4 & 8.8 & 7.5 & 10.1 & 0.215 & 7.3 \\
\hline & Minimum & 16.0 & 1.0 & 8.4 & nd & nd & nd & nd & nd & nd \\
\hline & Maximum & 437.0 & 227.0 & 250.9 & 54.7 & 41.5 & 45.8 & 71.4 & 1.01 & 40 \\
\hline & $\mathrm{N}$ & 111.0 & 101.0 & & 99.0 & 101.0 & 100.0 & 80.0 & 76 & 94 \\
\hline \multirow{5}{*}{ Group 2} & Average & 593.3 & 251.7 & 245.2 & 57.1 & 40.9 & 39.3 & 28.6 & 0,41 & 27.5 \\
\hline & SD & 244.2 & 67.3 & 115.4 & 29.9 & 24.8 & 38.0 & 45.9 & 0,2 & 19.8 \\
\hline & Minimum & 184.0 & 141.0 & 77.6 & 0.8 & 4.9 & 7.5 & nd & nd & 2.2 \\
\hline & Maximum & 1420.0 & 402.3 & 740.0 & 170.7 & 88.0 & 134.1 & 250,0 & 0,7 & 90.4 \\
\hline & $\mathrm{N}$ & 38.0 & 31.0 & & 30.0 & 33.0 & 33.0 & 33,0 & 22 & 31 \\
\hline \multirow{5}{*}{ Group 3} & Average & 400.0 & 175.4 & 61.9 & 10.8 & 84.7 & 17.3 & 18.6 & 0.57 & 3.4 \\
\hline & $\mathrm{SD}$ & 153.8 & 53.4 & 111.9 & 10.3 & 39.3 & 17.6 & 24.6 & 0.53 & 5.4 \\
\hline & Minimum & 95.0 & 85.2 & 0.0 & 0.1 & 23.0 & 0.5 & nd & nd & 0.1 \\
\hline & Maximum & 742.0 & 317.6 & 743.0 & 43.0 & 188.0 & 69.9 & 106.4 & 2.2 & 31.1 \\
\hline & $\mathrm{N}$ & 54.0 & 45.0 & & 46.0 & 46.0 & 46.0 & 44.0 & 42 & 35 \\
\hline
\end{tabular}

Group 2, on the other hand, has the highest magnesium content. High concentrations of sodium and fluoride are not expected in the groundwater of the SASG because they are not major components of high solubility minerals in amygdales. Calcite, on the other hand, is an abundant hydrothermal mineral filling amygdales of basalts; its solubilization increases the calcium and bicarbonate in groundwater. SASG has calcium bicarbonate composition and low concentrations of total dissolved solids (TDS). The hydrochemical characteristics of Group 1 indicate that this groundwater has recharge and circulation restricted to the SAG, while Groups 2 and 3 have higher concentrations of sodium, sulfate, chloride and fluoride, and this is in disagreement with the chemical and mineralogical compositions of the SASG. Thus, these groups probably represent groundwater with longer residence time and recharge from deeper sedimentary aquifers of the basin. The Paraná Basin has sedimentary lithostratigraphic units of marine and lagoon environments which contain soluble minerals such as carbonates, sulfates, and halides. These can be associated with high concentrations of ions mentioned above and total dissolved solids. Among these sedimentary units, the Irati Formation is significant. Wells of Groups 2 and 3 mark the hydraulic connection and mixing of groundwater of aquifers from different formations. According to Bittencourt et al.(2003), groundwater in the SASG is closely linked to rock structures, constituting itself a heterogeneous hydrogeochemical complex. 
They also defined three distinct classes of water, respectively calcium bicarbonate, calcium-sodium and calcium-magnesium. These compositional differences were interpreted as the result of interaction with Paleozoic groundwater.

The electrical conductivity presents average values of $275 \mu \mathrm{S} / \mathrm{cm}$ and maximum of $1,662 \mu \mathrm{S} / \mathrm{cm}$. Its spatial distribution is characterized by higher values in areas with higher density of fractures where there are hydraulic connections with deeper aquifer (Fig. 4).

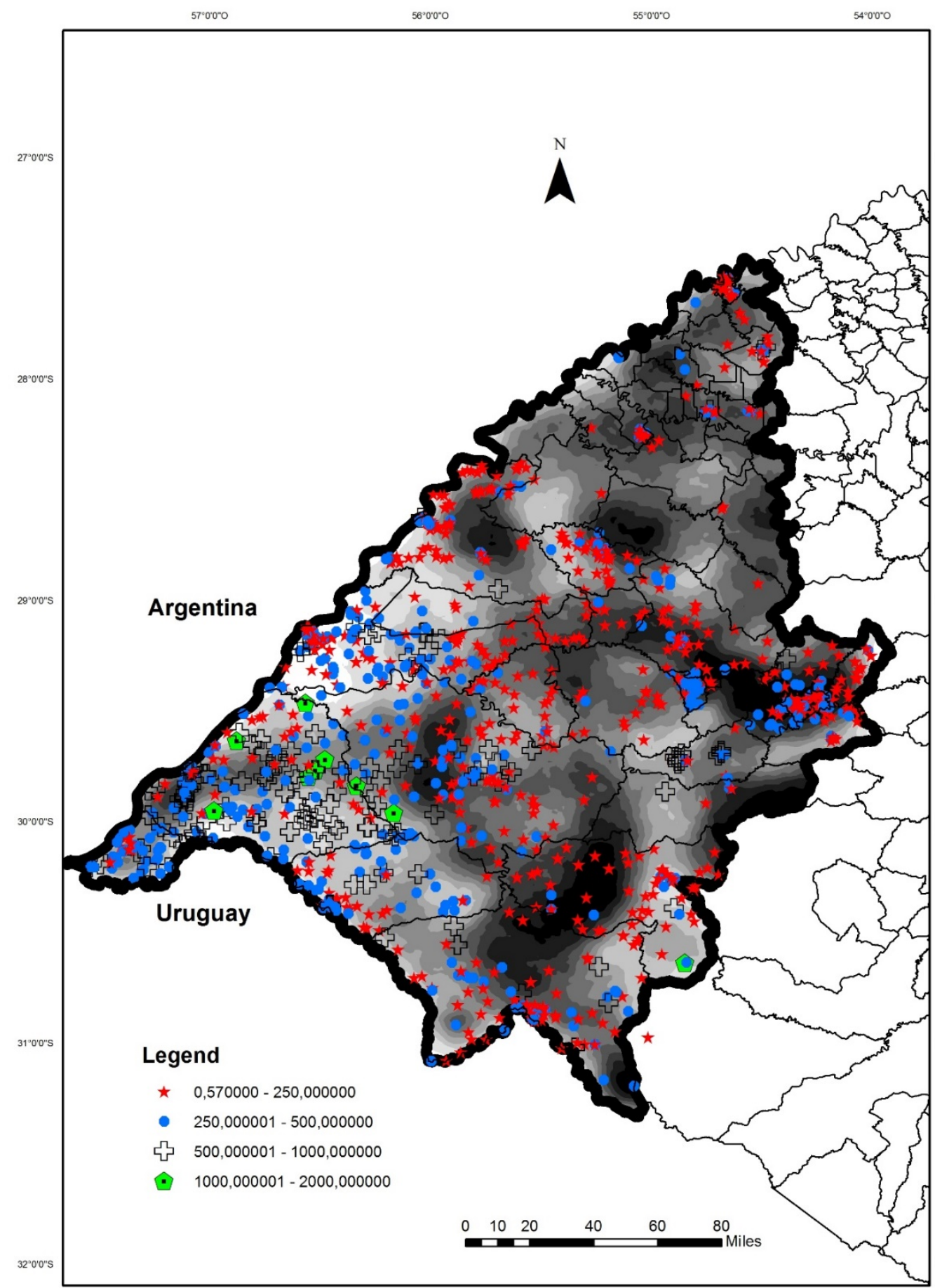

Figure 4 - Electrical Conductivity $(\mu \mathrm{S} / \mathrm{cm})$ plotted on the tectonic lineaments map. Symbology: Stars: 0- 250 $\mu \mathrm{S} / \mathrm{cm}$; Circle: 250 - $500 \mu \mathrm{S} / \mathrm{cm}$; Cross: 500 - 1000; lozenge: 1000-2000 $\mu \mathrm{S} / \mathrm{cm}$

Figura 4 - Condutividade Elétrica $(\mu \mathrm{S} / \mathrm{cm})$ plotada no mapa de lineamentos tectônicos. Simbologia: Estrelas: 0-

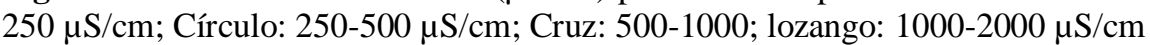


The highest electrical conductivity values are higher than $500 \mu \mathrm{S} / \mathrm{cm}$ and occur predominantly in the southwest portion of the study area, where the thickness of basalt is small or null (outcropping SAG). In the remaining region, the highest values are associated with high-density tectonic lineaments. The histogram of Figure 5 shows that only 203 wells (12\%) have electrical conductivity higher than $500 \mathrm{mg} / \mathrm{L}$, indicating that significant ion enrichment of groundwater by mixing occurs in a restricted number of wells. The electrical conductivity is directly related to TDS contents in all cases, and increases in aquifers with the residence time suggesting mixing of different aquifers (TWEED ET AL., 2005).

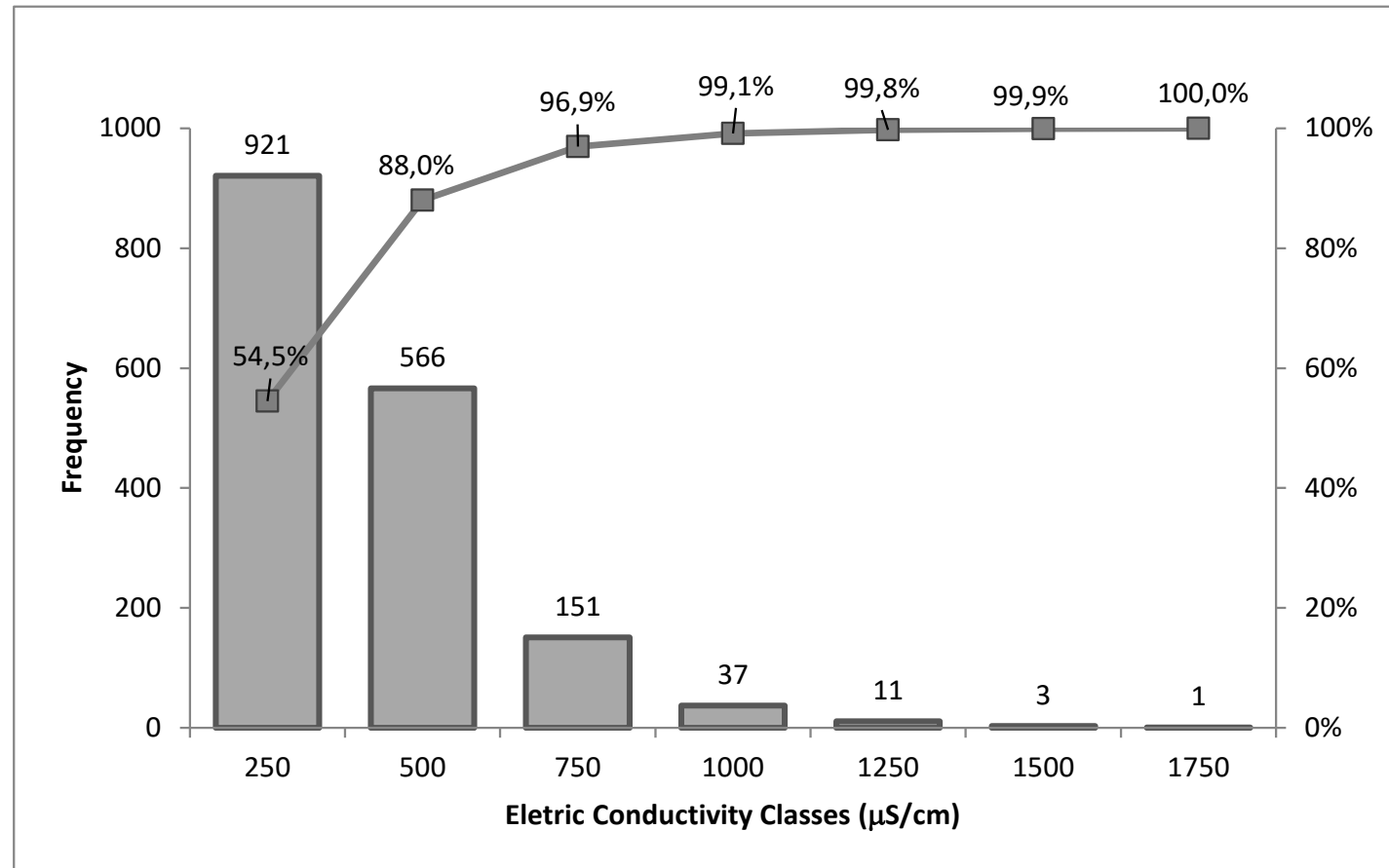

Figure 5 - Frequency histogram of the values of electrical conductivity. Most of the wells (921) have conductivity up to $250 \mu \mathrm{S} / \mathrm{cm}$. Only 5 wells have conductivity above $1000 \mu \mathrm{S} / \mathrm{cm}$

Figura 5 - Histograma de frequência dos valores de condutividade elétrica. A maioria dos poços (921) tem condutividade elétrica de até $250 \mu \mathrm{S} / \mathrm{cm}$. Apenas 5 poços tem condutividade acima de $1000 \mu \mathrm{S} / \mathrm{cm}$

Magnesium has average concentrations of $10.1 \mathrm{mg} / \mathrm{L}$ with maximum value of 90.4 $\mathrm{mg} / \mathrm{L}$. Group 2 differs from the others by presenting the highest values (Table 3 ). The occurrence of high magnesium concentrations is along zones of high tectonic lineaments density, which indicates that this ion may originate in the deep aquifers of the Paraná Basin. They ascended to the SASG through faults and fractures. Probably the magnesium source is dolomite, (Ca, $\mathrm{Mg}) \mathrm{CO}_{3}$, which is abundant in the Irati Formation.

Calcium presents average concentration of $23.7 \mathrm{mg} / \mathrm{L}$ and maximum of $170 \mathrm{mg} / \mathrm{L}$. The main source of calcium is probably the hydrolysis of calcite, as described in the following equation:

$$
\mathrm{CaCO}_{3}+\mathrm{H}_{2} \mathrm{O} \leftrightarrow \mathrm{Ca}^{++}+\mathrm{HCO}_{3}^{-}+(\mathrm{OH})^{-}
$$

Calcite is a common mineral in various hydrostratigraphic units of the Paraná Basin, such as the Rio Bonito, Irati and Estrada Nova Formations, SAG in its confined portions and filling amygdales and fractures of the SASG.

In Group 1, calcium and the bicarbonate are the most important ions and present a high correlation (Fig. 6), indicating that calcium source is mainly calcite from the basalt amygdales. The concentration of calcium is not affected significantly by other geochemical processes. In this way, it can be concluded that the Group 1 groundwaters have restricted circulation in the SASG, no mixtures with deeper waters, specially with the Permian hydroestratigrafic units. 


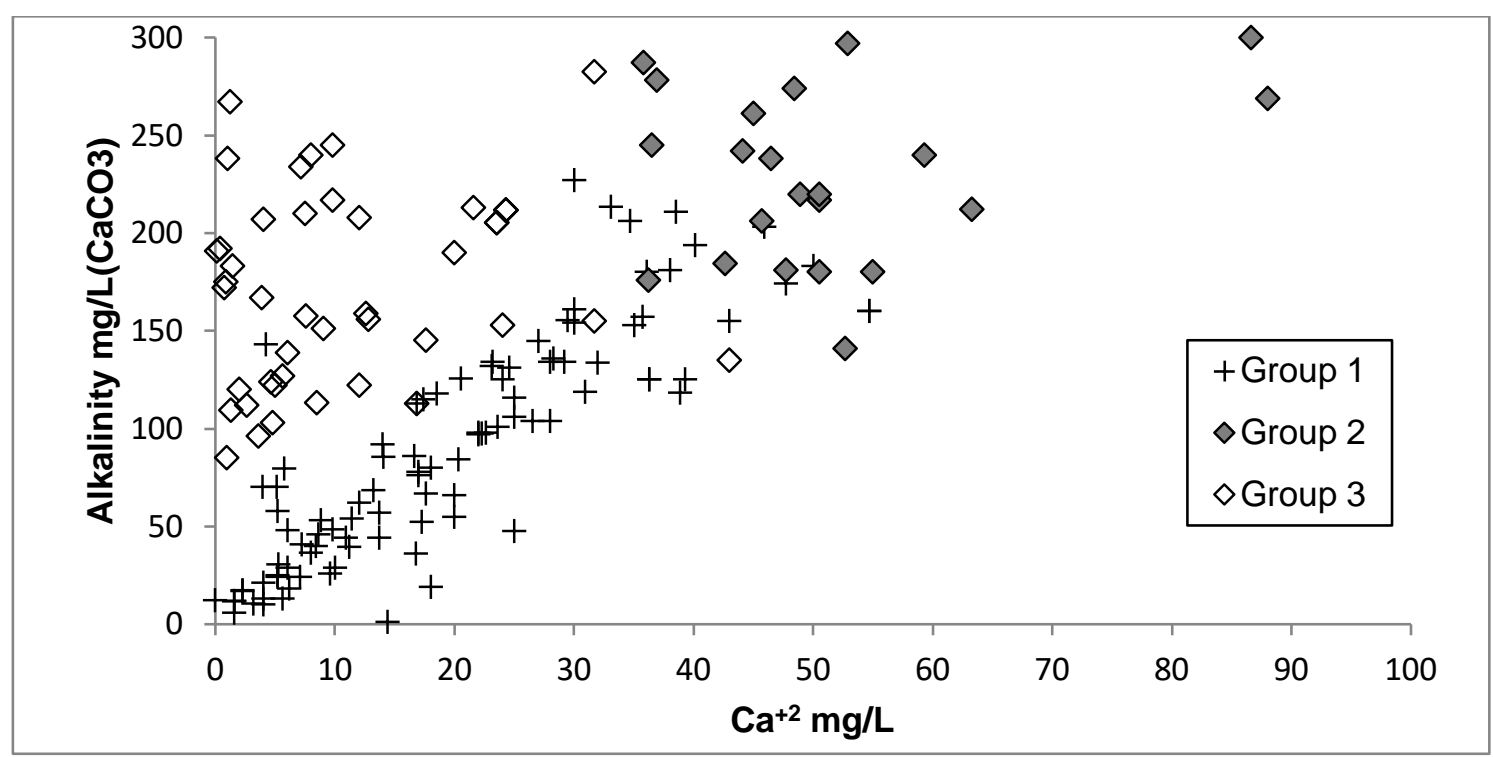

Figure 6 - Binary variation diagram showing good correlation of the Ca with alkalinity only in Group 1

Figura 6 - Diagrama de variação binária mostrando boa correlação do Ca com alcalinidade apenas no Grupo 1

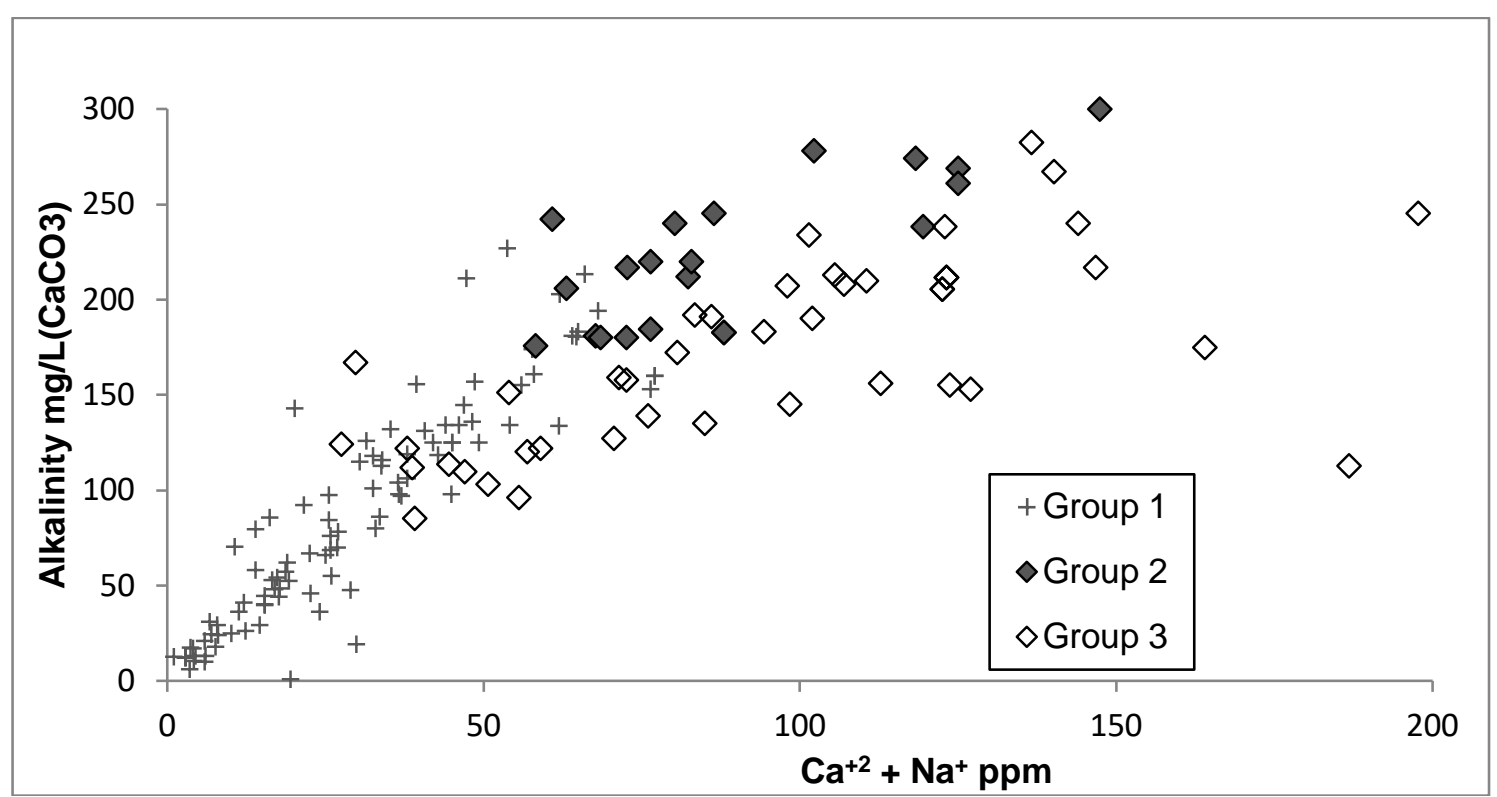

Figure 7 - Binary correlation diagram showing the correlation between $\mathrm{Ca}+\mathrm{Na}$ with alkalinity

Figura 7 - Diagrama de correlação binária mostrando a correlação do Ca + Na com a alcalinidade

Differently from Group 1, Groups 2 and 3 do not show correlation between calcium and bicarbonate (total alkalinity). However, there is high correlation in these groups between alkalinity and calcium plus sodium (Fig. 6 and 7). This suggests that the most probable source of calcium are the carbonates (calcite) from sedimentary rocks. This high correlation suggests ion exchange reactions between sodium and calcium in clay minerals in deep waters that are mixing with shallow waters.

$$
\begin{aligned}
& \mathrm{CaCO}_{3}+\mathrm{H}_{2} \mathrm{O} \leftrightarrow \mathrm{Ca}_{2+}+\mathrm{HCO}_{3}{ }^{-}+\mathrm{OH}^{-} \\
& (2 \mathrm{Na}-\mathrm{Clay})_{\text {adsorb. }}+\left(\mathrm{Ca}^{2+}\right)_{\text {dissol. }} \leftrightarrow(\mathrm{Ca}-
\end{aligned}
$$
Clay) adsorb. $+\left(2 \mathrm{Na}^{+}\right)_{\text {dissol. }}$

The exchange reactions restore the mass balance and the correlation between cations and anions, as the calcium tends to be adsorbed by the clay minerals.

In Group 3, the exchange between calcium and sodium is more intense because alkalinity has good correlation only with sodium (Fig. 8). The absence of soluble minerals containing sodium and carbonate 
requires the exchange reactions of calcium or magnesium by sodium to generate the correlation between sodium and alkalinity.
Calcium and magnesium originated from the hydrolysis or dissolution of calcite and dolomite.

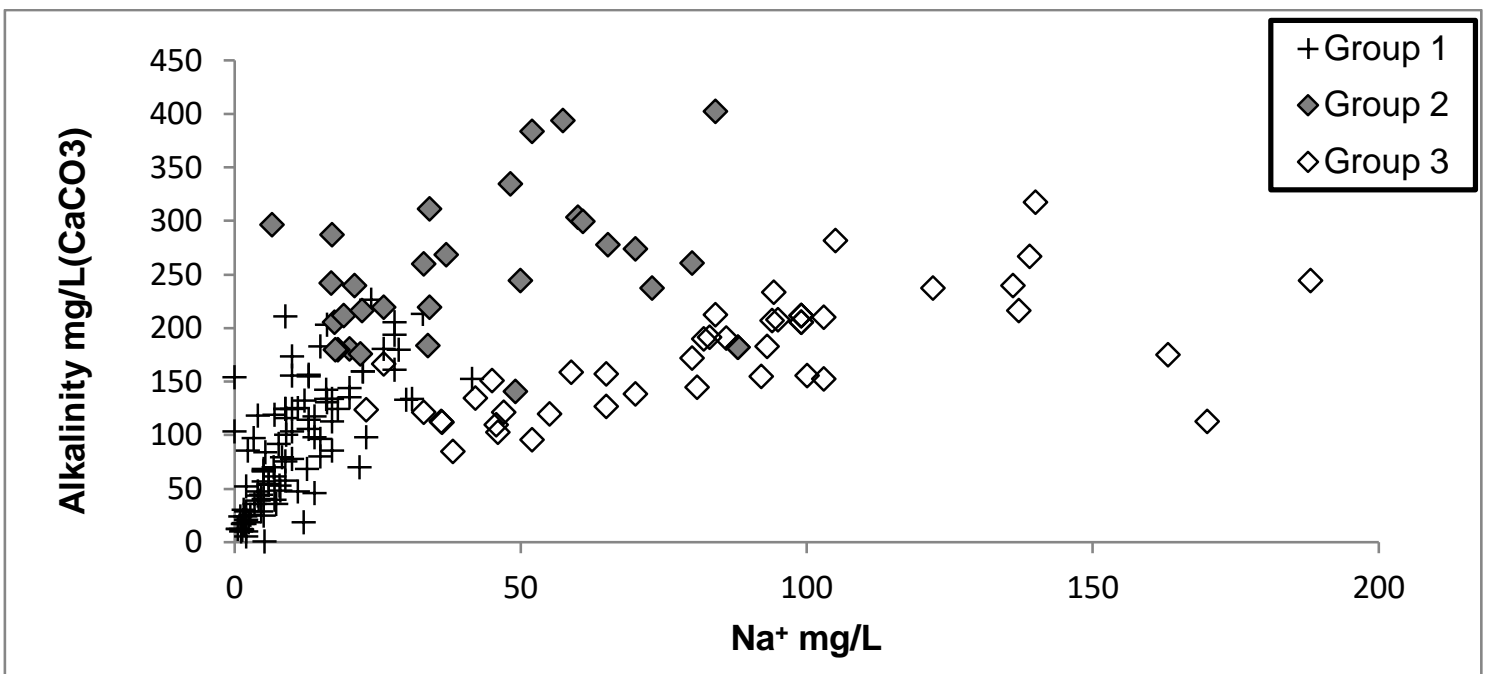

Figure 8 - Binary correlation diagram showing the good correlation between sodium and the alkalinity in Group 3

Figura 8 - Diagrama de correlação binária mostrando a boa correlação entre o sódio e a alcalinidade no Grupo 3

The diagrams of Figures 6, 7, 8 show that in the Group 2 about $50 \%$ of the calcium derived from calcite is adsorbed and replaced by sodium, while in Group 3 the exchange of calcium by sodium is up to $90 \%$. The anhydrite and gypsum can also be a source of calcium, because this soluble mineral is present in the basin, especially the Irati
Formation (HACHIRO, 1997). The anhydrite dissolution appears to be an effective salinization process of Group 3 groundwater, in addition to the hydrolysis of carbonates and cation exchange. This is indicated by the high correlation between alkalinity + sulfate and calcium + sodium (Fig. 9).

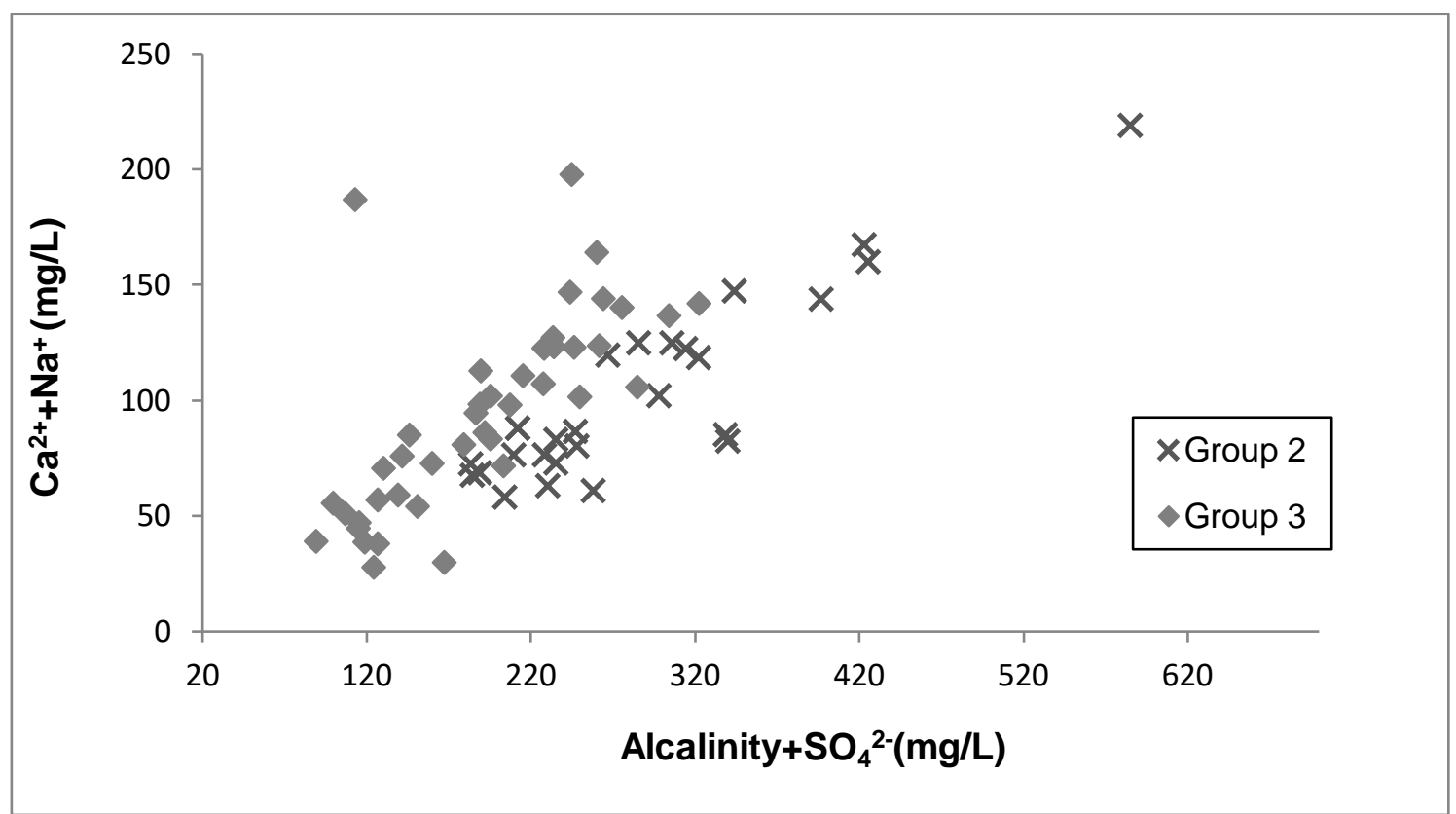

Figure 9 - Diagram of binary correlation of $\mathrm{Ca}+\mathrm{Na}$ with SO4+alkalinity

Figura 9 - Diagrama de correlação binária do $\mathrm{Ca}$ + Na com o SO4 + alcalinidade 
The average concentration of sodium is $38 \mathrm{mg} / \mathrm{L}$ and the maximum value is 291 $\mathrm{mg} / \mathrm{L}$ in the study area (Table 4 ). Sodium has very low concentration in Group 1 (average = $10.3 \mathrm{mg} / \mathrm{L}$ ), intermediary value in Group 2 (average $=40.9 \mathrm{mg} / \mathrm{L}$ ) and higher contents in Group 3 (average $=84.7 \mathrm{mg} / \mathrm{L}$ ). Sodium is the main indicator of the mixture in the SGAS between rainfall recharge and upward recharge of groundwater from deeper sedimentary hydrostratigraphic units. The main source of sodium is probably related to cation exchange with calcium, evident in diagrams of Figures 7 and 8.

Chloride has low concentrations in the study area with the average of about 15.5 $\mathrm{mg} / \mathrm{L}$. Group 1 has the lowest values with an average of $6.9 \mathrm{mg} / \mathrm{L}$ while Groups 2 and 3 have similar or a little higher contents. Concentrations higher than $50 \mathrm{mg} / \mathrm{L}$ are registered in six wells of Group 2 and three wells of Group 3. Group 2 has an average of 39.2 and Group 3 has an average of 17.3 $\mathrm{mg} / \mathrm{L}$. There is no correlation between chloride and sodium, indicating that their main sources are not the same (Fig. 10). As previously shown, sodium is related to the exchange of cations while the chlorine may be both from the meteoric water (low concentrations) and from dissolved salts (higher concentrations) in marine sedimentary rocks.

Fluoride has an average concentration of $0.5 \mathrm{mg} / \mathrm{L}$ with the higher values in Group 3 where the average is $0.9 \mathrm{mg} / \mathrm{L}$ and the maximum is $2.2 \mathrm{mg} / \mathrm{L}$. Approximately $20 \%$ of wells from Group 3 have fluoride concentration exceeding $1.5 \mathrm{mg} / \mathrm{L}$ which is the potability limit determined by World Health Organization. Similar to the sodium, fluoride appears to be originated in the deep sedimentary hydrostratigraphic units; it presents insignificant concentrations in the SASG resulting from groundwater mixtures. According to Kernet al.(2008), the main source of fluoride in the Paraná Basin aquifers is the Irati Formation, which has diagenetic fluorite associated mainly to bituminous shales.

\section{CONCLUSIONS}

High salinity in the SGAS and SAG resulted from mixing of water from two different origins. Water from meteoric recharge mixed with water originated in deeper formation in the Paraná basin. Nearly $90 \%$ of the wells from study area capture groundwater exclusively in the SASG and $10 \%$ in the SAG. Three groups of groundwater (Group 1, Group 2 and Group 3) were identified in the area using multivariate and discriminant statistical analysis. Groundwater of Group 1 have calciumbicarbonate compositions and the circulation is restricted to the SASG. There is no evidence of mixing with deeper groundwater coming from more saline aquifers of Paraná Basin. Groundwater of Groups 2 and 3 have sodiumbicarbonate and calcium-sodium bicarbonate compositions, respectively, and show evidence of mixing with groundwater coming from deeper aquifers. The contribution of deepwater coming from ascending recharge is greater in groundwater of Group 2 that present higher concentrations of sodium. In this group there is evidence of strong cation exchange by clay minerals, especially the calcium by sodium.

Irati Formation may be the main source of the high concentrations of sodium, fluoride, chloride and sulfate dissolved in SASG groundwater in the study area. The correlation between Eletric Conductivity and the density of fractures indicates that the mixing of groundwater is the most effective ion enrichment process of Serra Geral Aquifer System.

Fluoride and sodium originated probably in sedimentary rocks of Paraná Basin, mainly Irati Formation, and come into the SASG through the regional fractures by upward recharge (KERN ET AL., 2008). The concentrations of these elements have good correlation with densely fractured areas. The alkalinity presents good correlation with Sodium + Calcium in Group 3 and with Sodium in Group 2 indicating the occurrence of cations exchange with sorption of calcium 
and solubilization of sodium by clay minerals and organic matter.

The source of calcium and bicarbonate is mainly calcite present in the Serra Geral Aquifer System and in the sedimentary aquifers of the Paraná Basin. There is no other source to the bicarbonate so the correlation of alkalinity with sodium and calcium+sodium in Groups 2 and 3 result exclusively from cation exchange.

The anhydrite $\left(\mathrm{CaSO}_{4}\right)$ and gypsum $\left(\mathrm{CaSO}_{4} \cdot 2 \mathrm{H}_{2} \mathrm{O}\right)$ are other sources of calcium as well as sulphate in groundwater of study area (HACHIRO, 1997). This mineral occurs in the Irati Formation , so high sulfate concentrations in some wells of SGAS is indicative of groundwater rising from that lithostratigraphic unit.

Magnesium has the highest concentrations in groundwaters of Groups 1 and 2 indicating that hydrolysis of dolomite is an active process in the chemical evolution of these groundwater. It is important to note that the dolomite occurs mainly in Irati Formation (HACHIRO, 1997).

\section{ACKNOWLEDGEMENTS}

The Institute of Mathematics (UFRGS) for support with the statistical analysis. I also thank the UFRGS graduate programme.

\section{REFERENCES}

APPELO, C.A.J.; POSTMA, D. Geochemistry, Groundwater and Pollution. Cleaveland: CRC Press, 2005.

COMPANHIA DE PESQUISA E RECURSOS MINERAIS (CPRM). Mapa Hidrogeológico do Rio Grande do Sul. Relatório Final. Rio de Janeiro: 2005. Companhia de Pesquisa e Recursos Minerais. Área: Rio Grande do Sul. Brasill.

COMPANHIA DE PESQUISA DE RECURSOS MINERAIS (CPRM). Projeto Borda Leste da Bacia do Paraná: Integração geológica e Avaliação Econômica. Relatório Final de Pesquisa. São Paulo/Porto Alegre: 1986. Companhia de Pesquisa e Recursos Minerais. COMPANHIA DE PESQUISA E RECURSOS MINERAIS (CPRM). Sistema de Informações de Águas Subterrâneas: SIAGAS. Rio de Janeiro: 2016. Companhia de Pesquisa e Recursos Minerais. Acesso em:

$<$ http://siagasweb.cprm.gov.br/layout/.

BITTENCOURT, A.V.L; FILHO, E.F.R; HINDI, E.C; FILHO, A.C.B. A influência dos basaltos e de misturas com águas de aquíferos sotopostos nas águas subterrâneas do sistema aquífero serra geral na bacia do rio piquiri, Paraná-BR. Revista Brasileira de Águas Subterrâneas, n.17, 2003.

CLARK, I.D; FRITZ, P. Environmental Isotopes in Hidrogeology. Cleaveland: CRC Press, 1997.

GASTMANS, D; CHANG, H.K; HUTCHEON, I. Groundwater geochemical evolution in the northern portion of the Guarani Aquifer System (Brazil) and its relationship to diagenetic features. Applied Geochemistry Journal, v. 25, n. 1, p. 16-33, 2010.

HACHIRO. O Subgrupo Irati (Neopermiano) da Bacia do Paraná. USP, São Paulo, Brazil, 1997. 248 p. Tese (Doutoramento em Geociências). Universidade de São Paulo.

INSTITUTO BRASILEIRO DE GEOGRAFIA E ESTATÍSTICA - IBGE. Censo Agropecuário 2006. Rio Grande do Sul. Acesso em: <http:// ibge.gov.br/estadosat/temas.php?sigla=rs\&tema= censoagro.

KAZI, T.G; ARAIN, M.B; JAMALI, M.K, JALBANI; N, AFRIDI; H.I; SARFRAZ, R.A; BAIG, J.A; ABDUL, Q.S. Assesment of water quality of polluted lake using multivariate statistical techniques: A case study. Ecotoxicology and Environmental Safety. n.72, p.301-309. 2009.

KERN, M.L; VIERO, A.P; MACHADO, G. The fluoride in the groundwater of Guarani Aquifer System: the origin associated with black shales of Paraná Basin. Environmental Geology Journal, v. 55. n.6, p. 1219-1233, 2008.

KORETSKY, C. The significace of surface complexation reactions in hidrologic systems: a geochemist's perspective. Journal of Hidrology, v, 230, n. 3-4, p. 127-171, 2000.

MACHADO, J.L.F. Compartimentação Espacial e Arcabouço Hidroestratigráfico do Sistema Aquífero Guarani no Rio Grande do Sul, RS. Unisinos, São Leopoldo, Brazil, 2005. 
237 p. Tese (Doutoramento em Hidrogeologia). Universidade do Vale do Rio dos SinosUNISINOS.

MADRAMOOTOO, C.A. Sustainable groundwater use in agriculture. Irrigation and drainage, v.61, n.1, p.26-33, 2012.

MAYZELLE, M.M; VIERS, J.H; AZUARA, J.M; HARTER, T. Economic Feasibility of Irrigated Agricultural Land Use Buffers to Reduce Groundwater Nitrate in Rural Drinking Waters Source. Water, v, 7, p. 12-37, 2015.

MENG, S. X; MAYNARD J.B. Use of statistical analysis to formulate conceptual models of geochemical bahaviour: water chemical data from the Botucatu aquifer in São Paulo state, Brazil. Journal of Hidrology. v, 250, n. 1-4, p.78-97, 2001.

NANNI, A.S; ROISENBERG, A; HOLLANDA, M.H.B.M; MARIMON, M.P.C; VIERO, A.P; SCHEIBE, L.F. Fluoride in the Serra Geral Aquifer System: Source Evaluation Using Stable Isotopes and Principal Component Analyses. Journal of Geology Research, p.1-9, 2013.

PALÁCIO, H.A.Q; NETO, J.R.A; MEIRELES, A.C.M; ANDRADE， E.M; SANTOS， J.C.N; CHAVES, L.C.G. Similaridade e fatores determinates na salinidade das águas superficiais do Ceará, por técnicas multivariadas. Revista Brasileira de Engenharia Agrícola e Ambiental, v. 4, n. 4, p. 395-402, 2011.

PETALAS, C; PISINARAS, V; GEMITZI, A; TSIHRINTZIS, V, A; OUZOUNIS, K. Current conditions of saltwater intrusion in the coastal Rhodope aquifer system, northeastern Greece. Science Direct Journal, v.237, n. 1-3, p. 22-41, 2009.
STRECK, E.V; KAMPF, N; DALMOLIN, R.S.D; KLAMT, E; NASCIMENTO, P.C; SCHNEIDER, P; GIASSON, E; PINTO, L.F.S. Solos do Rio Grande do Sul. Porto Alegre: Emater/RS, 2008.

TEIXEIRA, G.V; VIERO, A.P. Caracterização estrutural das águas subterrâneas dos aquíferos juro-cretáceos do Oeste do Rio Grande do Sul. XXI Simpósio Brasileiro de Recursos Hídricos, 2015, Brasília. http://www.evolvedoc.com.br/sbrh/detalhes173_caracterizacao-estrutural-das-aguassubterraneas-dos-aquiferos-juro-cretaceos-dooeste-do-rio-grande-do-sul.

TWEED, S.O; WEAVER, T.R; CARTWRIGHT, I. Distinguishing groundwater flow paths in different fractured-rock aquifers using groundwater chemistry: Dandenong Ranges, southeast Australia. Hidrogeology Journal, v.13, n.5, p.771-786, 2005.

VICINI, L. Análise multivariada. Da teoria à prática. Santa Maria, Santa Maria, Brazil, 2005. 215 pp. Monografia de graduação. Universidade de Santa Maria.

WHITE, M.W. Geochemistry. West Sussex: WILEY-BLACKWELL, 2013. 